\title{
Engineering better chimeric antigen receptor T cells
}

\author{
Hao Zhang ${ }^{1}$, Pu Zhao ${ }^{1}$ and He Huang ${ }^{2^{*}}$ (1)
}

\begin{abstract}
CD19-targeted CART cells therapy has shown remarkable efficacy in treatment of B cell malignancies. However, relapse of primary disease remains a major obstacle after CART cells therapy, and the majority of relapses present a tumor phenotype with retention of target antigen (antigen-positive relapse), which highly correlate with poor CART cells persistence. Therefore, study on factors and mechanisms that limit the in vivo persistence of CART cells is crucial for developing strategies to overcome these limitations. In this review, we summarize the rapidly developing knowledge regarding the factors that influence CART cells in vivo persistence and the underlying mechanisms. The factors involve the CAR constructs (extracellular structures, transmembrane and intracellular signaling domains, as well as the accessory structures), activation signaling (CAR signaling and TCR engagement), methods for in vitro culture (T cells collection, purification, activation, gene transduction and cells expansion), epigenetic regulations, tumor environment, CD4/CD8 subsets, CART cells differentiation and exhaustion. Of note, among these influence factors, CART cells differentiation and exhaustion are identified as the central part due to the fact that almost all factors eventually alter the state of cells differentiation and exhaustion. Moreover, we review the potential coping strategies aiming at these limitations throughout this study.
\end{abstract}

Keywords: Chimeric antigen receptor T cells, Acute lymphoblastic leukemia, Relapse, Persistence, Differentiation, Exhaustion

\section{Background}

In recent years, chimeric antigen receptor $\mathrm{T}$ cells $(\mathrm{CAR}$ $\mathrm{T})$ emerged as one of the most promising approach in cancer treatment [1]. The most impressive responses have been achieved in patients with B cell malignancy, especially in refractory or relapsed $B$ acute lymphoblastic leukemia (B-ALL) treated by CAR $\mathrm{T}$ cells targeting CD19 with the complete remission (CR) rate reaching $90 \%$ [2-5]. However, 30-50\% of patients experienced leukemia relapse, the majority relapsed within 1 year after CAR T cells therapy [6], and with prolonged followup, the relapse rate may be much higher. Disease relapse

\footnotetext{
${ }^{*}$ Correspondence: huanghe@zju.edu.cn

${ }^{2}$ Bone Marrow Transplantation Center, The First Affiliated Hospital, School

of Medicine, Zhejiang University, No. 79 Qingchun Road, Hangzhou, China

Full list of author information is available at the end of the article
}

following CAR T cell therapy can be categorized into two major patterns: target antigen loss relapse or antigenpositive relapse. The mechanisms associated with loss of CD19 after CART cells therapy include the deletion or mutation of CD19 gene in leukemic cells $[7,8]$, abnormal CD19 RNA splicing because of decreased expression of splicing factor SRSF3 [8], leukemia lineage transformation caused by transcription factors PAX5 and EBF1 associated reprogramming of the pre- $\mathrm{B}$ cells $[9,10]$. The strategies for prevention or treatment of antigen loss relapse include administration of alternative antigen targeted CAR T cells, sequential infusion of different antigen targeted CAR T cells [11] and infusion of CAR T cells dual/multiple targeting different antigen [12]. Relapses of CD19-expressing leukemia in patients who achieved initial remission after CD19 targeting CART cells treatment highly correlates with poor CAR T cells persistence

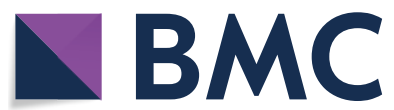

(c) The Author(s) 2020. This article is licensed under a Creative Commons Attribution 4.0 International License, which permits use, sharing, adaptation, distribution and reproduction in any medium or format, as long as you give appropriate credit to the original author(s) and the source, provide a link to the Creative Commons licence, and indicate if changes were made. The images or other third party material in this article are included in the article's Creative Commons licence, unless indicated otherwise in a credit line to the material. If material is not included in the article's Creative Commons licence and your intended use is not permitted by statutory regulation or exceeds the permitted use, you will need to obtain permission directly from the copyright holder. To view a copy of this licence, visit http://creativeco mmons.org/licenses/by/4.0/. The Creative Commons Public Domain Dedication waiver (http://creativecommons.org/publicdomain/ zero/1.0/) applies to the data made available in this article, unless otherwise stated in a credit line to the data. 
[2]. Therefore, study on factors and mechanisms that limit the in vivo persistence of CAR T cells is crucial for developing strategies to reduce the probability of tumor relapse and improve the long-term disease-free survival for patients who are treated with CAR T cells.

Human derived $\mathrm{T}$ lymphocytes engineered to express chimeric antigen receptors, which are expanded in vitro culture and then infused into patients exerting robust cytotoxicity after tumor antigen recognition and subsequent activation. Various factors in the process contribute to impact the in vivo persistence and durable antitumor effects of CAR T cells. In this review, we summarize the rapidly developing knowledge regarding the influence factors and mechanisms of poor CAR T cells persistence, and also the potential strategies to overcome these limitations.

\section{CAR constructs}

\section{Extracellular structures}

The extracellular structure conventionally includes single-chain variable fragment $(\mathrm{scFv})$ and spacer. $\mathrm{ScFv}$ is the antigen-binding domain of CAR structure, which is composed of a single heavy and light chain of monoclonal antibody connected by a linker. A murine derived $\mathrm{scFv}$ has been reported to induce HLA-restricted T cellmediated cellular immune response or humoral immune response [13], while humanized $\mathrm{scFv}$ is expected to reduce the immunogenicity of CAR, thereby avoiding immune mediated rejection and improving the persistence and therapeutic efficacy of CAR T cells $[14,15]$. The different antigen-targeted $\mathrm{scFv}$ on the $\mathrm{T}$ cells membrane has different impact on CAR T cells fates. Sustained tonic $\mathrm{CD} 3 \zeta$ phosphorylation in GD2 targeting CAR, which is triggered by antigen-independent clustering of CAR scFv, can induce early exhaustion of CAR $\mathrm{T}$ cells, and such tonic signaling is present to varying degrees in all CARs studied [16]. Moreover, the density of CAR surface expression which can be controlled by using different eukaryotic promoters has a substantial impact on antitumor efficacy and persistence of CAR T cells [17]. Low level expression of CARs driven by weaker rather than by stronger promoters results in significant higher numbers of circulating and tumor infiltrating CAR $T$ cells in mice [18]. As is known that the affinity of CAR binding to antigen is the premise of CAR T cells function, but lower rather than higher affinity CAR-incorporated CAR T cells showed enhanced expansion, better overall and event-free survival and lower toxicity compared with FMC63 CAR T cells [19].

The extracellular spacer domain of CAR has no signaling function, but the length and composition of the extracellular spacer domain influence the spatial configurations and Fc receptor binding, and further the in vivo persistence and antitumor effects of CART cells [20, 21]. Therefore, optimizing the design of $\mathrm{scFv}$ and spacer can be effective approaches to improve the therapeutic efficacy of CAR T cells.

\section{Transmembrane and intracellular domains}

The transmembrane domain which is usually derived from CD8 or CD28 connects the extracellular antigen binding domain with the intracellular signaling domain. Compared with $\mathrm{T}$ cells expressing CARs with CD28 hinge and transmembrane domains, $\mathrm{T}$ cells expressing CARs with CD8 $\alpha$ counterparts produce lower levels of cytokines and exhibit lower levels of activation-induced cell death (AICD) [22].

The intracellular structure domain involving $\mathrm{CD} 3 \zeta$ and co-stimulatory molecules is essential to full $\mathrm{T}$ cell activation. However, CAR incorporating all three $\mathrm{CD} 3 \zeta \mathrm{immu}-$ noreceptor tyrosine-based activation motifs (ITAMs) may foster counterproductive $\mathrm{T}$ cell differentiation and exhaustion. CAR encoding a single ITAM balanced the replicative capacity of long-lived memory cells and the acquisition of effective antitumor function, favoring persistence of CAR $\mathrm{T}$ cells with enhanced therapeutic potency [23].

First-generation CAR $\mathrm{T}$ cells utilizing $\mathrm{CD} 3 \zeta$ signaling alone showed limited efficacy in clinical trials probably owing to the AICD or the lack of long-term T cells expansion in vivo. The co-stimulatory molecules are critical for CAR T cells expansion and persistence following adoptive therapy. Second-generation CAR using combination of $\mathrm{CD} 3 \zeta$ and an additional co-stimulatory signaling domain such as CD28 or 4-1BB demonstrated remarkable efficacy with enhanced in vivo expansion and persistence [24-28]. Subsequently, CARs incorporating other co-stimulatory signaling moieties such as CD27, ICOS and OX40 [29-31], or multiple co-stimulatory molecules in tandem emerged and demonstrated different characteristics on their biological functions (Table 1). CD19-targeted CAR $T$ cells incorporating the 4-1BB co-stimulatory domain show more persistent than those incorporating CD28 in clinical trials [16, 32, 33]. Compared to CAR T cells with CD28, 4-1BB is associated with more antiapoptotic proteins and reduced $T$ cells exhaustion $[16,34]$. Changing a single amino acid residue asparagine to phenylalanine in CD28 domain (CD28-YMFM) promotes durable antitumor effects with reduced CAR $\mathrm{T}$ cells differentiation and exhaustion as well as increased Th17 skewing [35]. Engineered CD28 lacking lck binding moiety (Delta-CD28) may also be a promising co-stimulator for better CAR T cells persistence [36]. After antigen stimulation, $\mathrm{CD} 27$-bearing CAR $\mathrm{T}$ cells proliferate with upregulated $\mathrm{Bcl}-\mathrm{X}_{\mathrm{L}}$ expression and resisted apoptosis [29]. CAR containing inducible co-stimulator (ICOS) 
Table 1 Characteristics of different co-stimulatory molecules incorporated in CAR T cells

\begin{tabular}{|c|c|c|}
\hline $\begin{array}{l}\text { Co-stimulatory } \\
\text { molecules }\end{array}$ & Characteristics & Author and year \\
\hline CD28 & Facilitates full and sustained T cell activation, growth and survival & Maher et al. (2002) [28] \\
\hline CD28-YMFM & Reduces T cell differentiation and exhaustion with increased skewing toward Th17 cells & Guedan et al. (2020) [35] \\
\hline Delta-CD28 & $\begin{array}{l}\text { Better persistence with higher expression of genes involving cell division, glycolysis, fatty acid } \\
\text { oxidation, and oxidative phosphorylation }\end{array}$ & Gulati et al. (2020) [36] \\
\hline $4-1 B B$ & Be associated with more anti-apoptotic proteins and reduced T cells exhaustion & $\begin{array}{l}\text { Long et al. (2015) [16] } \\
\text { Li et al. (2018) [34] }\end{array}$ \\
\hline CD27 & Upregulates $B C l-X_{L}$ protein expression and resists apoptosis & Song et al. (2012) [29] \\
\hline ICOS & $\begin{array}{l}\text { Presents the characteristic of TH17 cells with increased expression of IL-17A, IL-17F, and IL-22 follow- } \\
\text { ing antigen recognition }\end{array}$ & Guedan et al. (2014) [30] \\
\hline OX40 & Represses IL-10 secretion and counteracts self-repression & Hombach et al. (2012) [31] \\
\hline TLR2 & $\begin{array}{l}\text { Generates memory T cells, expresses pro-survival proteins and abolishes the suppression of regula- } \\
\text { tory } T \text { cells }\end{array}$ & Lai et al. (2018) [39] \\
\hline MYD88/CD40 & $\begin{array}{l}\text { MYD88 is a TLR adaptor molecule. CD40 contributes to memory formation and rescuing T cells } \\
\text { from exhaustion }\end{array}$ & $\begin{array}{l}\text { Mata et al. (2017) [45] } \\
\text { Collinson-Pautz et al. (2019) [44] }\end{array}$ \\
\hline
\end{tabular}

generates IL-17-producing effector cells with the characteristic of TH17 cells showing enhanced persistence in vivo [30,37]. OX40 co-stimulatory signaling effectively represses IL-10 secretion, and contributes to counteract self-repression, thus facilitates a prolonged CAR T cells response [31, 38]. Toll-like receptor 2 (TLR2)-incorporated CAR $\mathrm{T}$ cells demonstrate improved expansion and persistence due to the capacity of generating memory $\mathrm{T}$ cells, expressing pro-survival proteins and abolishing the suppression of regulatory T cells [39-41]. CD40 signaling contributes to memory formation and rescuing $\mathrm{T}$ cells from exhaustion [42, 43]. Combination of CD40 and TLR adaptor molecule MyD88 signaling in CAR T cells results in improved persistence and enhanced efficacy in hematological malignancy and solid tumor models [44, 45].

\section{Accessory structures}

Considering the dependence on certain cytokines and interactions with endogenous immune cells, CAR T cells with accessory genetic modifications are designed to secrete cytokines or express ligands in order to benefit from autocrine or survive in the tumor microenvironment (Table 2). IL-7 is known to enhance the proliferation and survival of $\mathrm{T}$ cells, and co-expression of IL-7 improves NKG2D-based CAR T cells therapy on prostate cancer by enhancing the expansion, inhibiting cell apoptosis and exhaustion [46]. The strategy of co-expressing IL-7 receptor which triggers the IL-7 signaling axis but is unresponsive to extracellular cytokine increased the persistence and antitumor activity of CAR T cells [47]. CCL12 and CCL19 is chemoattractant for $\mathrm{T}$ cells and

Table 2 The application of accessory genetic modifications in CAR T cells

\begin{tabular}{|c|c|c|}
\hline Accessory molecules & Functions & Author and year \\
\hline IL-7 or IL-7R & Inhibits T cells apoptosis and exhaustion & $\begin{array}{l}\text { He et al. (2020) [46] } \\
\text { Shum et al. (2017) [47] }\end{array}$ \\
\hline IL-7/CCL12 & Improves the survival and infiltration of CAR T cells and DCs in tumor & Luo et al. (2020) [48] \\
\hline IL-7/CCL19 & $\begin{array}{l}\text { Improves the infiltration and anti-tumor response of both recipient conventional T cells and CART } \\
\text { cells in tumor }\end{array}$ & Adachi et al. (2018) [49] \\
\hline $\begin{array}{l}\text { IL-15/IL-21 } \\
\text { IL-2Rß/YXXQ }\end{array}$ & $\begin{array}{l}\text { Generates stem cell memory and central memory } T \text { cells } \\
\text { activates the JAK-STAT pathway and triggers gene expression profiles analogous to those triggered } \\
\text { by IL-21 }\end{array}$ & $\begin{array}{l}\text { Batra et al. (2020) [50] } \\
\text { Kagoya et al. (2018) [51] }\end{array}$ \\
\hline $\mathrm{IL}-12$ & Mitigates Treg-suppression and reprogram tumor-associated macrophages and dendritic cells & $\begin{array}{l}\text { Pegram et al. (2012) [52] } \\
\text { Koneru et al. (2015) [53] }\end{array}$ \\
\hline $\mathrm{IL}-23$ & Increases granzyme B and decreases PD-1 expression & Ma et al. (2020) [54] \\
\hline CD40L & Facilitates $T$ cells memory formation and induces increased immunogenicity on tumor cells & Curran et al. (2015) [56] \\
\hline 4-1BBL & $\begin{array}{l}\text { Increases CD8/CD4 ratio and decreases T cells exhaustion due to the activation of IRF7/IFN- } \beta \text { path- } \\
\text { way }\end{array}$ & Zhao et al. (2015) [57] \\
\hline ICOSL & Enhances PI3K signaling pathway and upregulates the expression of Bcl2 & Hu et al. (2019) [58] \\
\hline
\end{tabular}


DCs. Combined expression of IL-7 and CCL21 significantly improved survival and infiltration of CAR T cells and DCs in tumor [48]. IL-7 and CCL19 expression in CAR $T$ cells improves immune cell infiltration in the tumor, where both recipient conventional $\mathrm{T}$ cells and administered CAR $\mathrm{T}$ cells generated memory responses against tumors [49]. CAR T cells with transgenic expression of IL-15 and IL-21 show superior in vivo expansion, persistence and antitumor activity against hepatocellular carcinoma with a higher percentage of stem cell memory and central memory populations after manufacturing [50]. CAR encoding a truncated cytoplasmic domain from IL-2 receptor $\beta$-chain (IL-2R $\beta$ ) and a STAT3-binding tyrosine- $\mathrm{x}-\mathrm{x}$-glutamine (YXXQ) motif activates the JAK/STAT pathway and triggers gene expression profiles analogous to those triggered by IL-21, facilitating a better CAR T cells persistence [51]. Introduction of IL-12 into the tumor microenvironment holds the promise of improving CAR $\mathrm{T}$ cells cytotoxic function, mitigating Treg-suppression and reprogramming tumor-associated macrophages and dendritic cells [52, 53]. IL-23, consisting of IL-23 $\alpha$ p19 and IL-12 $\beta$ p 40 subunits, is known to promote proliferation of memory $\mathrm{T}$ cells, and engineered CAR $\mathrm{T}$ cells with expression of the p40 subunit show improved antitumor capacity with increased granzyme $\mathrm{B}$ and decreased PD-1 expression via autocrine IL-23 signaling [54]. CD40L/CD40 is important to T cells activation, proliferation and memory formation $[42,55]$. The altered tumor phenotype with increased immunogenicity (upregulation of CD80, CD86, HLA and Fas) which is susceptible to apoptosis can be indued by CD40L expressing CAR T cells [56]. 4-1BBL armored CAR $\mathrm{T}$ cells exhibited balanced tumoricidal function and increased $\mathrm{T}$ cell persistence accompanied by elevated $\mathrm{CD} 8 / \mathrm{CD} 4$ ratio and decreased exhaustion due to the induction of the IRF7/IFN- $\beta$ pathway [57]. Accessory ICOSL resulted in enhanced CAR $T$ cells activity via enhanced PI3K signaling pathway and upregulated expression of $\mathrm{Bcl} 2$ [58].

\section{In vitro cell culture}

Generally, in vitro culture process of CAR T cells includes $\mathrm{T}$ cell collection, purification, activation, gene transduction and cell expansion. The methods applied in each step may influence the cell composition or state of the final product (Fig. 1).

\section{T cells collection and purification}

Variability in CAR T cells expansion is in part due to the contamination of the starting peripheral blood mononuclear cells (PBMC) concentrated with monocytes. Among patients whose CAR T cells expanded poorly, manufacturing incorporating a monocyte depleting plastic adherence step could yield an adequate dose of CAR T cells for clinical use [59]. A density-based negative selection for $\mathrm{T}$ cells enrichment using antibody cocktail presents the advantage of leaving $\mathrm{T}$ cells free of antibodies [60], thereby reducing the probability of

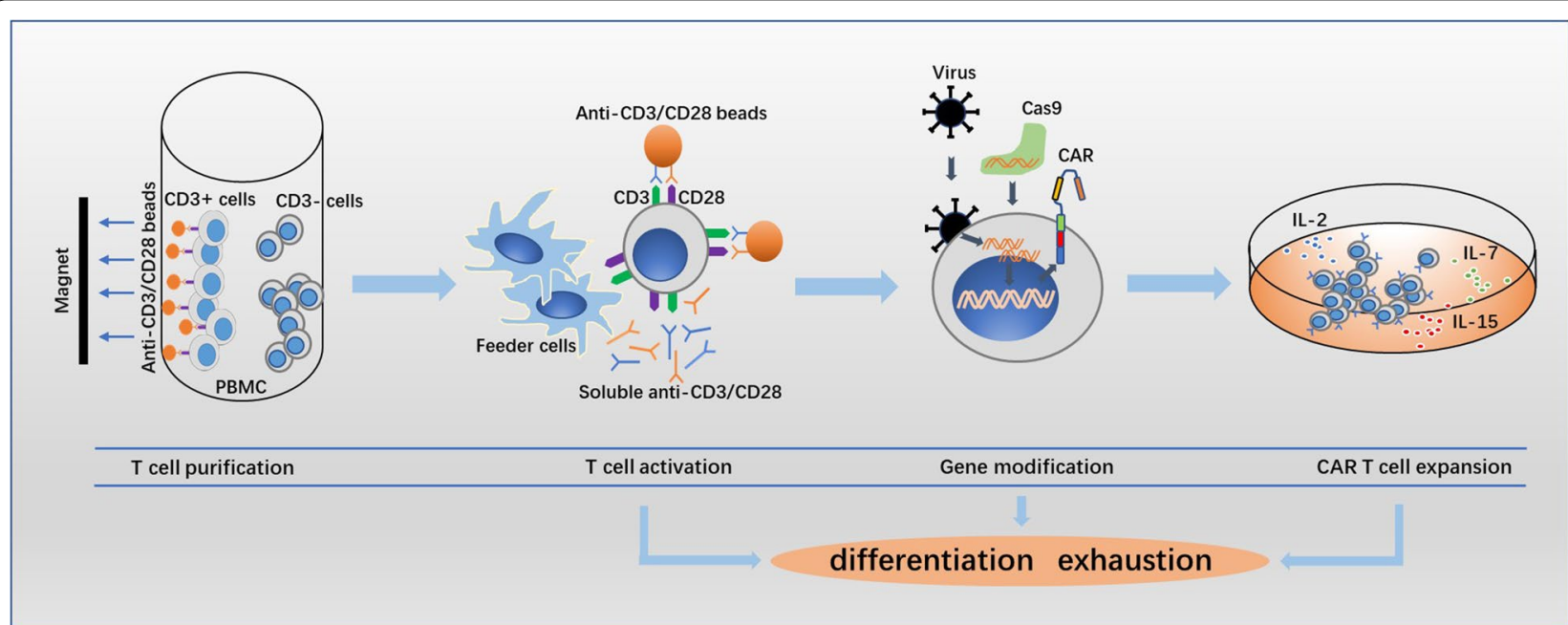

Fig. 1 The methods applied in the process of chimeric antigen receptor T cells culture influence cell differentiation and exhaustion state of the final product. In vitro culture process of CART cells mainly includes T cell collection, purification, activation, gene transduction and cell expansion. Enrichment of T cells by magnetic adsorption of CD3/CD28 antibody coated beads is commonly used but the purity cannot be guaranteed. Different methods for T cell activation leading to different activation strength or activity of pathways, and the viral or non-viral gene editing resulting in random or site-specific gene integration, ultimately influence the state of cell differentiation and exhaustion. Reducing the duration of ex vivo culture yields less differentiated CART cells, and addition of cytokines such as IL-7, IL-15 and IL-21 increases the frequencies of memory stem CART cells 
excessive or inadequate cells activation. The most commonly used method for enrichment of $\mathrm{T}$ cells is magnetic adsorption using CD3/CD28 antibody coated beads, but the purity of T cells can't be guaranteed. The CAR gene may be transduced into leukemic cells during $\mathrm{T}$ cell manufacturing, and its product bound in cis to the CD19 epitope on the surface of leukemic cells, masking it from recognition by and conferring resistance to CD19-targeted CAR T cells [61]. Therefore, the existence of CAR-tumor cells needs to be taken into consideration when relapse occurs, and the methods for $\mathrm{T}$ cells purification need further exploration.

\section{T cells activation}

Anti-CD3/CD28 beads stimulation provided a suitable activation for clinical use of genetic modification of $\mathrm{T}$ cells [62], as well as the application of soluble anti-CD3/ CD28 antibody or anti-CD3/CD28 coated plate. Of note, in addition to anti-CD3 for T cell activation, anti-CD28 is needed to avoid $\mathrm{T}$ cell anergy. Compared to soluble anti$\mathrm{CD} 3$, anti-CD3/CD28 beads stimulated greater CD4+ T cells growth, but both stimulated similar CD8 expansion [63]. The conjugation of anti-CD137 antibodies to conventional anti-CD3/CD28 beads results in a significant increase in the expansion capacity for $\mathrm{CD} 8$ cytotoxic $\mathrm{T}$ cells [64]. Besides, irradiated feeder cells from PBMC in the presence of anti-CD3 antibody have been shown to be a high effective approach for expansion of CD8+ T cells with a high ratio of central memory-like $T$ cells [65].

\section{Gene transduction}

The most common and effective methods for gene transduction in CAR $\mathrm{T}$ cells production is using viral vectors carrying CAR transgene, including $\gamma$-retrovirus and lentivirus. These vectors are widely used for $\mathrm{T}$ cells modification and are successful in clinical trials due to the stable and durable expression of target genes by integration into the genome of host cells. However, the random integration of viral vectors may result in variegated transgene expression which ultimately influence the in vivo persistence of CAR T cells. The non-viral gene editing, especially the CRISPR/Cas9-mediated site-specific gene integration, results in uniform CAR expression, which averts tonic CAR signaling and establishes effective internalization and re-expression of the CAR following single or repeated exposure to antigen, delaying effector $\mathrm{T}$ cells differentiation and exhaustion [66].

\section{CART cells expansion}

In order to obtain sufficient amount of CAR $\mathrm{T}$ cells, a proper duration for $\mathrm{T}$ cell expansion ex vivo is necessary. Most protocols for $\mathrm{T}$ cells engineering routinely expand
$\mathrm{T}$ cells for 9-14 days, but there is a trend of shortening recently. The potential for engraftment and persistence of CAR $\mathrm{T}$ cells are related to the state of $\mathrm{T}$ cells differentiation, and reducing the duration of ex vivo culture could limit cells differentiation and enhance the efficacy of CAR T cells therapy [67].

IL-2 is necessary for T cell culture, but it may drive T cell differentiation. Low concentration or short-term use of IL-2 favors generation of early memory $\mathrm{T}$ cells over effector phenotypes during CAR $\mathrm{T}$ cells expansion, thereby enhancing therapeutic efficacy and saving production cost $[68,69]$. Addition of soluble IL-7, IL-15 and/or IL-21 in the process of cell culture can reduce the CAR T cells terminal differentiation and increase the frequency of memory stem cells, yielding improved in vivo persistence [70-72].

\section{Activation signaling CAR signaling}

T-cell activation is a necessary step in the production of CAR T cells, and the robust cytotoxicity of CAR T cells depend on the antigen recognition by chimeric antigen receptors and subsequent activation signaling. However, excessive activation drives $\mathrm{T}$ cells differentiation and exhaustion [73], which rationalizes the notion that appropriate activation is essential to optimize therapeutic potency and durability of CAR T cells. Modulation of multiple links in the activation signal pathway can affect the state of CAR T cells differentiation and exhaustion. With CARs encoding a single ITAM, CAR T cells show less differentiation and exhaustion [23]. Inhibition of PI3K preserves a less differentiated state of CAR $\mathrm{T}$ cells without affecting cell expansion [74, 75]. MAP Kinase inhibition protects tumor-infiltrating CD8 T cells from death driven by chronic TCR stimulation [76]. Akt inhibitor treated CAR $\mathrm{T}$ cells present an early memory phenotype and superior antitumor efficacy owing to the intranuclear localization of $\mathrm{T}$ cell memory associated transcriptional regulator FOXO1 [77, 78]. Different from unmodified $T$ cells, CAR-modified $T$ cells with sustained activation signaling induced by spontaneous aggregation of CAR molecules lead to cell differentiation and exhaustion during ex vivo expansion, limiting their therapeutic efficacy and in vivo persistence [16, 74]. Thus, in addition to direct regulating activation signaling, it might be useful to modulate the density of CAR molecules on the cell surface in order to prevent the aggregation of CARs induced sustained cell activation. This is consistent with the observations that the level of CAR surface expression correlates with the in vivo persistence of CAR $T$ cells, and the density of CAR can be controlled by modifying the promoters. 


\section{TCR signaling}

The initiation of $\mathrm{T}$ cell antigen receptor (TCR) signaling is a key step that result in $\mathrm{T}$ cell activation and the orchestration of an adaptive immune response. Theoretically, CAR $\mathrm{T}$ cells retain the structure and function of TCR which can still recognize specific antigens and transduce activation signals. The dual stimulation of CAR and TCR may lead to loss of CD8 CAR T cells efficacy owing to excessive activation induced cell exhaustion and apoptosis [79]. Allogeneic CD19- specific CAR T cells- mediated anti-lymphoma activity without causing a significant increase in the incidence of graft-versus-host disease (GVHD) also suggests that both the TCR and CAR are engaged to accelerate $T$ cells exhaustion [80]. CAR T cells with TCR knock-out exhibit high anti-leukemic effects and long-term persistence in the absence of alloreactivity [81]. Directing a CD19-targeted CAR to the alpha constant locus of TCR which undergoes structural disruption not only results in uniform CAR expression, but also enhances CAR T cells therapeutic potency with delayed effector $\mathrm{T}$ cells differentiation and exhaustion [66].

\section{Epigenetic regulation}

Epigenetic regulation including DNA methylation, histone modification and chromatin remodeling plays a very important role in $\mathrm{T}$ cells differentiation by modulating the transcription of differentiation related genes on and off [82]. The loss of methylcytosine dioxygenase TET2 promotes CD8 T cell memory differentiation [83]. A single CAR $\mathrm{T}$ cell with disrupted TET 2 gene by CAR transgene insertion expanded continuously so as to induced a durable complete remission in a patient with chronic lymphocytic leukemia (CLL), and further research demonstrated that TET2-disrupted CAR $\mathrm{T}$ cells exhibited superior expansion with a central memory phenotype [84]. DNA methyltransferase DNMT3a which localizes to the TCF7 promoter is a crucial regulator of CD8 early effector cell differentiation [85]. The demethylation drug decitabine treated CD123 CAR T cells are enriched in genes associated with naïve and early memory $\mathrm{T}$ cells with decreased expression of DMNT3a and DNMT1 [86]. The role of epigenetic regulation in $\mathrm{T}$ cell exhaustion also should not be neglected. Exhaustion related hypermethylation which was found in tumor infiltrating $\mathrm{T}$ cells can be reversed by decitabine [87]. Therefore, epigenetic modification can be utilized to develop new type of CAR T cells with superior performance in clinical application.

\section{CD4 and CD8 CAR T cells}

It is generally believed that the efficacy of adoptive cell therapy is most often attributed to CD8 T cells [88], and infusion of CD8 CAR T cells alone was sufficient for long-term B-cell eradication $[89,90] . \mathrm{CD} 4 \mathrm{~T}$ cells are known for their helper function and to intrinsically evoke cytolytic activities by enhancing CD8 $\mathrm{T}$ cells activity through cytokine production [91]. However, CD4 CAR $\mathrm{T}$ cells demonstrated comparable effectiveness in directly killing target tumor cells both in vitro and in vivo [79, 92, 93]. In terms of characteristics of killing dynamics, CD4 CAR T cells show initial slower granzyme B secretion and tumor killing, but are less prone to AICD and exhaustion compared to CD8 counterparts, which confers CD4 CAR $\mathrm{T}$ cells a relative better persistence following antigen exposure [93-96]. In most of reported clinical trials, patients have received CAR $\mathrm{T}$ cells products comprising random compositions of CD4 and CD8 cells, but the variation may have influenced the efficacy. Defining the 1:1 ratio of CD4:CD8 CAR T cells confers superior antitumor reactivity in vivo, indicating the synergistic antitumor effects of the two subsets [97, 98].

\section{Tumor environment}

Some certain types of cancer cells protect themselves from the attack of immune system by expression of immune inhibitory ligands such as PD-L1 [99, 100], and release of the immune inhibitory cytokines such as indoleamine 2,3-dioxygenase (IDO) [101], arginase [102], TGF- $\beta$ [103] and IL-4 [104], which impair the activity of CAR $\mathrm{T}$ cells through different mechanisms. Moreover, tumor orchestrates an immune inhibitory microenvironment, containing regulatory immune cells such as regulatory $\mathrm{T}$ cells (Tregs) and myeloid derived suppressor cells (MDSCs), which also compromise the effector function of CAR T cells through inhibitory ligands (e.g. PD-L1) and/or cytokines (e.g., IL-10, TGF- $\beta$ and arginase) [105, 106]. Tumor infiltrating CAR $T$ cells rapidly lose their cytolytic and cytokine secretion capacity, and tend to be exhaustion [107]. After "rest" away from the tumor microenvironment, the expression levels of inhibitory receptors (e.g., PD1, TIM3 and LAG3) decreased dramatically [108]. These results suggest that the immunosuppressive tumor microenvironment significantly impacts the effective antitumor responses generated by CAR $T$ cells (Fig. 2). It has been reported that refractory diffuse large B-cell lymphoma with high expression of PD-L1 failed to respond to CD19-targeted CAR T cells therapy, but following PD-1 blockade, CAR $\mathrm{T}$ cells expanded with clinically significant antitumor response [109]. IDO inhibits CAR T cells activity through the action of tryptophan metabolites, while fludarabine and cyclophosphamide which are frequently administered before CD19-targeted CAR $T$ cells infusion downregulate the expression of IDO in B cell malignancies and thereby improve CAR T cells activity [101]. In order to eliminate the suppressive effect of TGF- $\beta$ in tumor environment, 


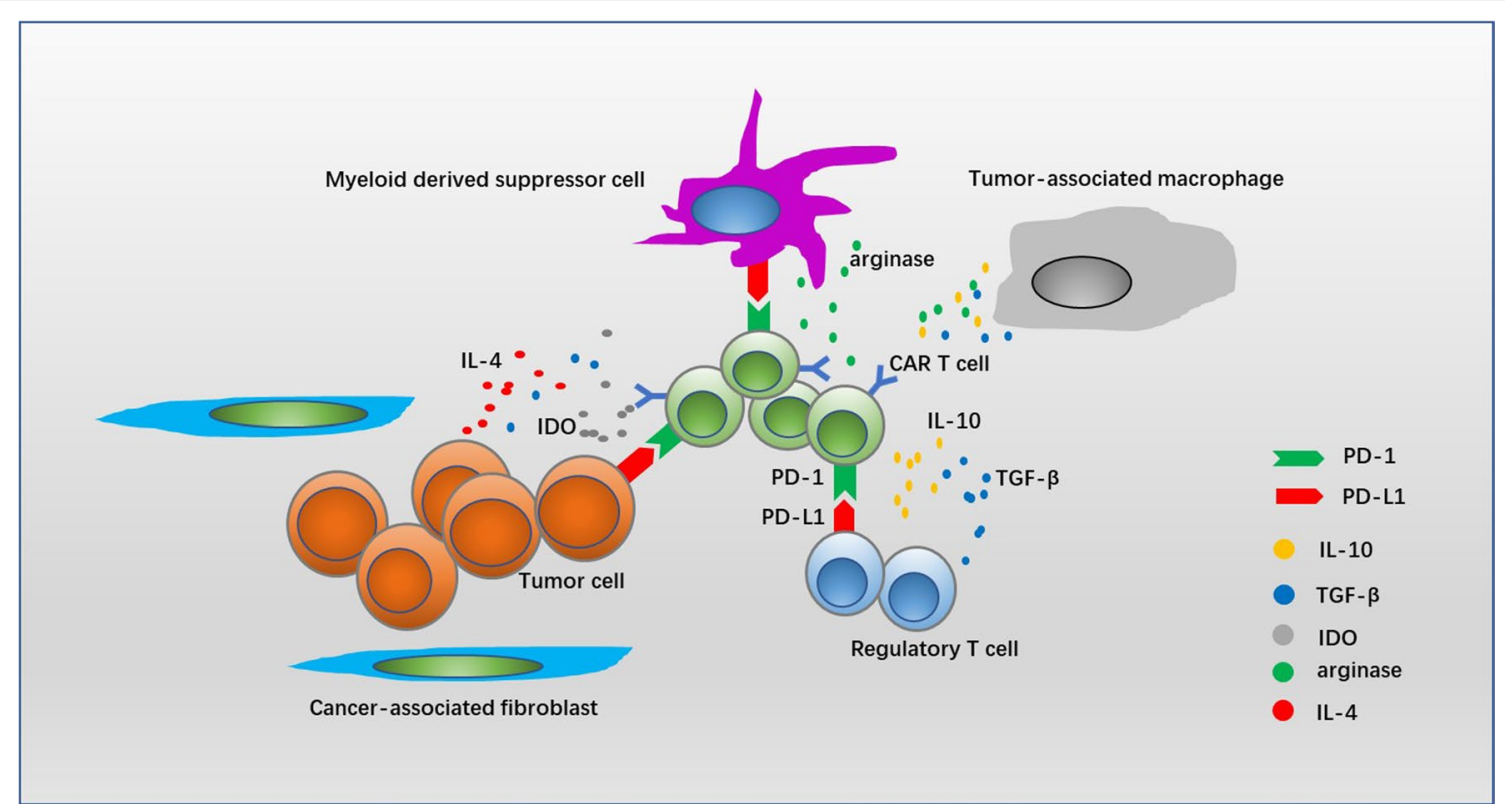

Fig. 2 Tumor cells which orchestrate an immune inhibitory microenvironment compromise the activity of CART cells. Tumor cells, immunosuppressive cells (e.g., myeloid derived suppressor cells and regulatory T cells) and tumor-associated stroma cells inhibit the activity of CART cells by expression of inhibitory molecules (e.g., PDL1) and release of inhibitory cytokines such as IL-10, indoleamine 2,3-dioxygenase (IDO), transforming growth factor- $\beta$ (TGF- $\beta$ ), arginase and IL-4. In this immunosuppressive microenvironment, tumor infiltrating CART cells rapidly lose their cytolytic and cytokine secretion capacity, and tend to be exhaustion. Approaches targeting suppressive factors can improve the efficacy of CART cells

CAR T cells expressing the dominant-negative TGF- $\beta$ RII demonstrate resistance to exhaustion and long-term persistence in prostate cancer mouse models [103]. Fusing the IL-4 receptor exodomain to IL-7 receptor endodomain inverts the inhibitory effects of tumor-derived IL-4 and instead promotes CAR T cells proliferation [104]. Pharmacological administration such as fludarabine and/ or cyclophosphamide targeting Tregs, doxorubicin or alltrans retinoic acid targeting MDSCs effectively impairs regulatory immune cell-induced immunosuppression, therefore fostering the efficacy of CAR $\mathrm{T}$ cells therapy [110-112]. Besides, tumor-associated stroma, represented by cancer-associated fibroblasts (CAFs), can also contribute to form a highly pro-tumorigenic immunosuppressive microenvironment that mediates immunotherapeutic resistance, while combining the stroma and tumor-targeted CAR T cells significantly enhanced overall antitumor activity [113].

\section{CAR T cells differentiation and exhaustion}

From the above, CAR structure, activation signaling, epigenetic regulations, methods for in vitro culture and tumor environment, all of which independently or collaboratively influence the state of CAR T cells differentiation and/or exhaustion in various degrees through different mechanisms (Fig. 3). Thus, differentiation and exhaustion may be the central part and share a certain range of common pathways in impacting the CAR T cells in vivo persistence.

\section{The stage of CAR T cells differentiation}

According to the stage of cell differentiation, $\mathrm{T}$ cell can be categorized as Naive $\mathrm{T}$ cell $\left(\mathrm{T}_{\mathrm{N}}\right)$, stem cell memory $\mathrm{T}$ cell $\left(\mathrm{T}_{\mathrm{SCM}}\right)$, central memory $\mathrm{T}$ cell $\left(\mathrm{T}_{\mathrm{CM}}\right)$, memory effector $\mathrm{T}$ cell $\left(\mathrm{T}_{\mathrm{EM}}\right)$, effector $\mathrm{T}$ cell $\left(\mathrm{T}_{\mathrm{EF}}\right)$. It is well defined that the therapeutic efficacy and in vivo persistence of CAR $\mathrm{T}$ cells significantly correlate with their differentiation stage. CAR $\mathrm{T}$ cells products rich in $\mathrm{T}_{\mathrm{N}}, \mathrm{T}_{\mathrm{CM}}$ and $\mathrm{T}_{\mathrm{SCM}}$ exhibit superior antitumor responses and long-term persistence in vivo $[98,114,115]$. Both of CD8 and CD4 CAR $T$ cells derived from $\mathrm{TN}$ and $\mathrm{T}_{\mathrm{CM}}$ are more effective than those from $\mathrm{T}_{\mathrm{EM}}$ [98]. Transcriptomic profiling revealed that CAR $\mathrm{T}$ cells from complete-responding patients with CLL were enriched in memory-related genes, whereas CAR T cells from non-responders upregulated programs involving effector differentiation, and sustained remission was associated with an elevated frequency of memory-like $\mathrm{T}$ cells before CAR $\mathrm{T}$ cells generation [116].

Most of current approaches for maintaining durable memory CAR $\mathrm{T}$ cells in vivo are improving the capacity of memory formation in the stage of manufacture. 


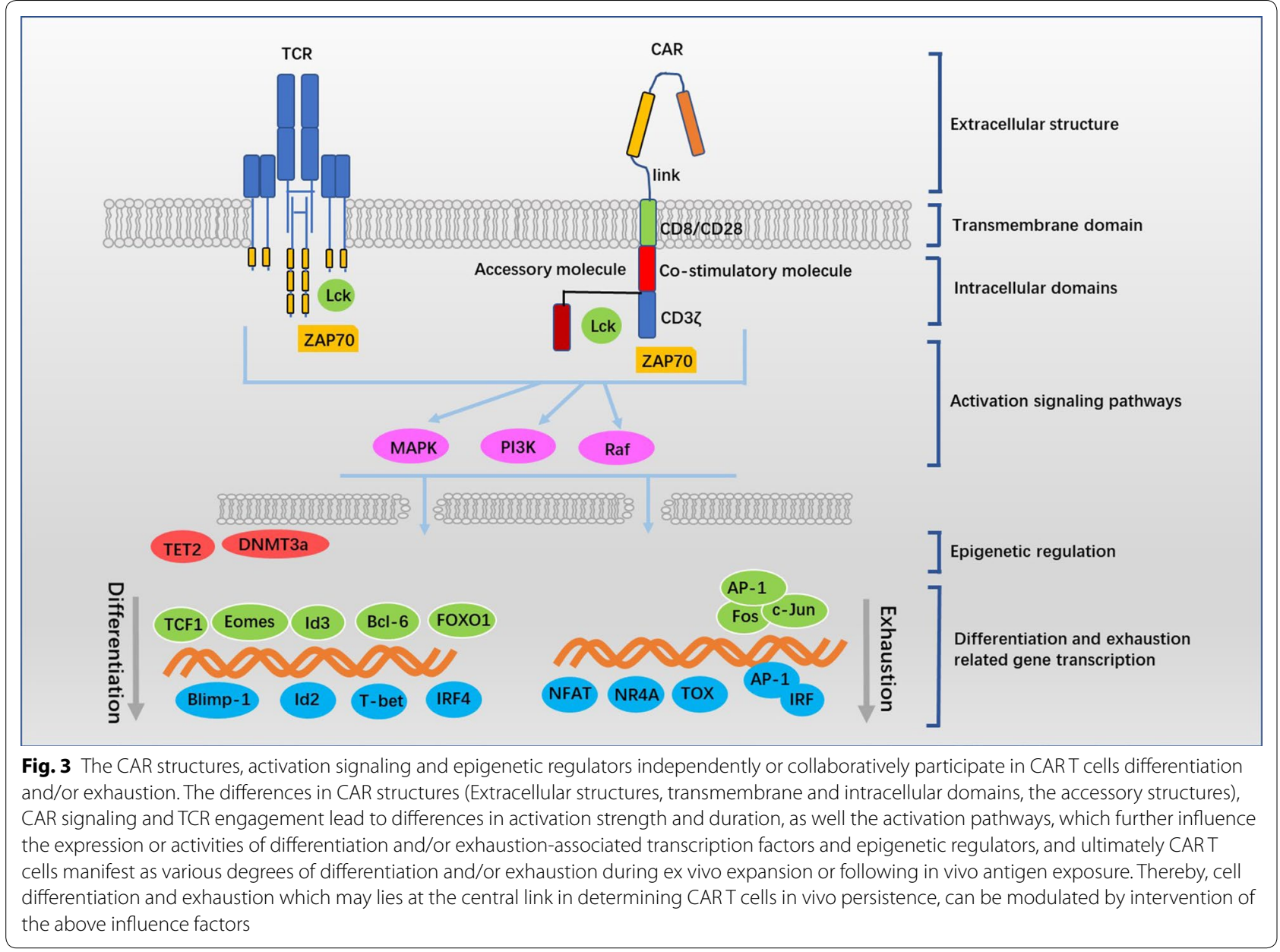

These approaches including design refinement of CAR structure, control of activation signaling, epigenetic regulations and optimization of in vitro culture, ultimately regulate the expression or activities of $\mathrm{T}$ cell differentiation-associated transcription factors (TFs). Numerous TFs have been identified as critical regulators of conventional $\mathrm{CD} 8 \mathrm{~T}$ cell differentiation, including memory-associated TFs (e.g., TCF-1, Eomes, Id3, Bcl-6 and FOXO1) and effector-associated TFs (e.g., T-bet, Blimp1 , Id2, and IRF4) $[117,118]$. Considering that CAR T cells may share the similar differentiation-associated transcriptional regulations as conventional $\mathrm{T}$ cell, gene modifications or small molecule drugs targeting these TFs may be promising for CAR T cells memory maintenance.

Upon antigen exposure, naive $\mathrm{T}$ cells are activated and differentiate into multiple types of effector $\mathrm{T}$ cells, and the differentiation is accompanied by robust proliferation, transcriptional, epigenetic and metabolic reprogramming $[117,119]$. Following the peak of effector expansion, the resolution of inflammation and the clearance of antigen, most activated $\mathrm{T}$ cells die, but a subset persists and transits into the memory $\mathrm{T}$ cells pool which maintains the ability to rapidly reactivate effector functions upon re-stimulation [120]. CAR $\mathrm{T}$ cells may undergo the similar process of differentiation following antigen recognition after therapeutic infusion. However, the strategies of in vivo intervention for CAR $\mathrm{T}$ cells memory maintenance still need further exploration.

\section{CART cells exhaustion}

CAR $\mathrm{T}$ cells present less effective always because of exhaustion which occurs both in vivo and in vitro. During in vitro expansion, spontaneous CAR molecule aggregation-induced sustained tonic signaling lead to CAR $\mathrm{T}$ cells exhaustion [16]. After therapeutic infusion, upon repeated antigen stimulation, part of CAR $\mathrm{T}$ cells enter into an exhausted state which is defined by poor effector function, sustained expression of inhibitory receptors (e.g., PD1, TIM3 and LAG3) and widespread transcriptional and epigenetic alterations distinct from that of functional effector or memory $\mathrm{T}$ cells $[73,120,121]$. 
At the level of transcription, AP-1 related bZIP-IRF families have been identified as major modulators that drive exhaustion-associated gene expression. Exhaustion-associated dysfunction resulted from increased levels of AP-1/IRF complexes leads to a functional deficiency in activating AP-1 Fos/Jun heterodimers, whereas c-Jun overexpression prevents phenotypic and functional hallmarks of exhaustion and improves antitumor efficacy [60]. NFAT/NR4A axis which controls the expression of multiple inhibitory receptors plays a crucial role in $\mathrm{T}$ cell exhaustion, and CAR T cells lacking all three NR4A transcription factors results in tumor regression and prolonged survival in tumor-bearing mice [122, 123]. Transcription factor TOX cooperates with NR4A to regulate $\mathrm{T}$ cells exhaustion [124, 125], and disruption of TOX activity could be a promising strategy for enhancing therapeutic potency of CAR T cells.

Inhibitory receptors such as PD1, TIM3 and LAG3 are recognized as the markers of $\mathrm{T}$ cells exhaustion, although they also increase significantly in response to cell activation [126]. Tumor cells or tissues up-regulate the inhibitory ligands (e.g., PDL1) upon immune attack, while CAR T cells up-regulate the inhibitory receptors (e.g., PD1) in response to antigen exposure, and the PDL1/ PD1 pathway significantly inhibits CAR $T$ cells activity. Thus, intervention of PDL1/PD1 pathway emerges as a promising approach for reinvigorating CAR $\mathrm{T}$ cells in certain clinical application. Strategies for intervention of PDL1/PD1 axis developed recently involving CAR T cells modified to secrete PD1 blocking scFv [127], disruption of PD1 by gene editing [128, 129], and the application of monoclonal antibodies targeting PDL1 or PD1. Of note, compared to 4-1BB/CAR T cells, CD28/CAR T cells are more susceptible to exhaustion that PD-1/PD-L1 blockade confers a priority $[130,131]$. And even, downregulation of three inhibitory receptors (PD1, TIM3 and LAG3) simultaneously on CAR $\mathrm{T}$ cells show increased tumor infiltration and durable tumor control [132].

The exhaustion of CAR T cells limits their efficacy and durability in vivo, but in certain application, exhaustion may present a positive effect. Due to the exhausting alloreactivity caused by cumulative TCR and CAR signaling, allogeneic CAR T cells demonstrated reduced risk of GVHD in mice model $[80,133]$.

\section{Conclusions}

CD19-targeted CAR T cells therapy has shown remarkable efficacy in treatment of B cell malignancies, which opens up a new horizon in the field of cancer therapy. However, the ability of cancer cells to modify themselves and adapt the new survival stress, the complicated regulatory mechanisms of CAR T cells and tumor microenvironment, as well as the adverse effects such as cytokines release syndrome and on-target off-tumor toxicity [134], make adoptive $\mathrm{T}$ cells immunotherapy still face many challenges. Scientists are making great efforts to reveal the mechanisms and propose reliable solutions to impediments in CAR T cells therapy. In this rapidly developing field, CAR T cells with superior performance will be applied in more and more cancers.

\begin{abstract}
Abbreviations
CAR: Chimeric antigen receptor; sCFv: Single-chain variable fragment; B-ALL: $B$ acute lymphoblastic leukemia; CLL: Chronic lymphocytic leukemia; CR: Complete remission; AICD: Activation-induced cell death; SRSF3: Serine and arginine rich splicing factor 3; PAX5: Paired box 5; EBF1: Early B cell factor 1; ITAMs: Immunoreceptor tyrosine-based activation motifs; ICOS: Inducible co-stimulator; CD28-YMFM: Changing a single amino acid residue asparagine to phenylalanine in CD28 domain; MyD88: Myeloid differentiation primary response gene 88; BCI-XL: BCL2L1, BCL2 like 1; OX40: TNFRSF4, tumor necrosis factor receptor superfamily member 4;TLR2: Toll-like receptor 2; Tregs: Regulatory T cells; MDSCs: Myeloid derived suppressor cells; CAFs: Cancer-associated fibroblasts; TCR: T cell receptor; PBMC: Peripheral blood mononuclear cells; TN: Naive T cell; TSCM: Stem cell memory T cell; TCM: Central memory T cell; TEM: Memory effector T cell; TEF: Effector T cell; GVHD: Graft-versus-host disease; CRISPR/Cas9: Clustered regularly interspaced short palindromic repeats/ CRISPR-associated 9; MAPK: Mitogen-activated protein kinase; JAK/STAT: Janus kinase and signal transducer and activator of transcription; IRF7/IFN- $\beta$ : Interferon regulatory factor 7 and interferon- $\beta$; PI3K: Phosphatidylinositol 3 kinase; TCF-1: Transcription factor-1; TET2: Tet methylcytosine dioxygenase 2; DNMT3a: DNA methyltransferase 3 alpha; Eomes: Eomesodermin; Id2/3: Inhibitor of DNA binding 2/3; BCl-6: B cell leukemia/lymphoma 6; FoxO1: Forkhead box 01; T-bet: TBX21,T-box transcription factor 21; Blimp-1: PRDM1, PR/SET domain 1; IRF4: Interferon regulatory factor 4; NFAT: Nuclear factor of activated T; NR4A: Nuclear receptor subfamily 4 group A; TOX: Thymocyte selection associated high mobility group box; IL-2: Interleukin-2; IL-4: Interleukin-4; IL-7: Interleukin-7; IL-15: Interleukin-15; IL-21: Interleukin-21; IL-12: Interleukin-12; IL-23: Interleukin-23; CCL12/19: C-C motif chemokine ligand 12/19; IDO: Indoleamine 2,3-dioxygenase; TGF- $\beta$ : Transforming growth factor- $\beta$; PD-1: Programmed death 1; TIM3:T cell immunoglobulin domain and mucin domain 3 ; LAG3: Lymphocyte activating 3.
\end{abstract}

\section{Acknowledgements}

Not applicable.

\section{Author contributions}

$\mathrm{HZ}$ wrote the manuscript. $\mathrm{PZ}$ and $\mathrm{HH}$ provided suggestions and revisions. All authors contributed to the writing of the review. The authors read and approved the final manuscript.

\section{Funding}

This work was supported by grants from the National Natural Science Foundation of China (81730008).

\section{Availability of data and materials}

The material supporting the conclusion of this review has been included within the article.

Ethics approval and consent to participate

This is not applicable for this review.

Consent for publication

This is not applicable for this review.

\section{Competing interests}

The authors declare that they have no competing interest.

\section{Author details}

${ }^{1}$ Department of Hematology, The Third Affiliated Hospital of Wenzhou

Medical University, Wenzhou, China. ${ }^{2}$ Bone Marrow Transplantation Center, 
The First Affiliated Hospital, School of Medicine, Zhejiang University, No. 79 Qingchun Road, Hangzhou, China.

Received: 23 October 2020 Accepted: 19 November 2020 Published online: 02 December 2020

\section{References}

1. Yu S, Li A, Liu Q, Li T, Yuan X, Han X, et al. Chimeric antigen receptor T cells: a novel therapy for solid tumors. J Hematol Oncol. 2017;10(1):78.

2. Maude SL, Frey N, Shaw PA, Aplenc R, Barrett DM, Bunin NJ, et al. Chimeric antigen receptor $T$ cells for sustained remissions in leukemia. N Eng J Med. 2014;371(16):1507-17.

3. Grupp SA, Kalos M, Barrett D, Aplenc R, Porter DL, Rheingold SR, et al. Chimeric antigen receptor-modified $T$ cells for acute lymphoid leukemia. N Eng J Med. 2013;368(16):1509-18.

4. Cruz CR, Micklethwaite KP, Savoldo B, Ramos CA, Lam S, Ku S, et al. Infusion of donor-derived CD19-redirected virus-specific T cells for B-cell malignancies relapsed after allogeneic stem cell transplant: a phase 1 study. Blood. 2013;122(17):2965-73.

5. Hu Y, Wu Z, Luo Y, Shi J, Yu J, Pu C, et al. Potent anti-leukemia activities of chimeric antigen receptor-modified T cells against CD19 in Chinese patients with relapsed/refractory acute lymphocytic leukemia. Clin Cancer Res. 2017;23(13):3297-306.

6. Shah NN, Fry TJ. Mechanisms of resistance to CART cell therapy. Nat Rev Clin Oncol. 2019;16(6):372-85.

7. Orlando EJ, Han X, Tribouley C, Wood PA, Leary RJ, Riester M, et al. Genetic mechanisms of target antigen loss in CAR19 therapy of acute lymphoblastic leukemia. Nat Med. 2018;24(10):1504-6.

8. Sotillo E, Barrett DM, Black KL, Bagashev A, Oldridge D, Wu G, et al. Convergence of acquired mutations and alternative splicing of CD19 enables resistance to CART-19 immunotherapy. Cancer Discov. 2015:5(12):1282-95.

9. Gardner R, Wu D, Cherian S, Fang M, Hanafi LA, Finney O, et al. Acquisition of a CD19-negative myeloid phenotype allows immune escape of MLL-rearranged B-ALL from CD19 CAR-T-cell therapy. Blood. 2016;127(20):2406-10.

10. Jacoby E, Nguyen SM, Fountaine TJ, Welp K, Gryder B, Qin H, et al. CD19 CAR immune pressure induces B-precursor acute lymphoblastic leukaemia lineage switch exposing inherent leukaemic plasticity. Nat Commun. 2016;7:12320

11. Wang N, Hu X, Cao W, Li C, Xiao Y, Cao Y, et al. Efficacy and safety of CAR19/22 T-cell cocktail therapy in patients with refractory/relapsed B-cell malignancies. Blood. 2020;135(1):17-27.

12. Tong $C$, Zhang $Y$, Liu Y, Ji X, Zhang WY, Guo Y, et al. Optimized tandem CD19/CD20 CAR-engineered T cells in refractory/relapsed B cell lymphoma. Blood. 2020;136(14):1632-44.

13. Lamers $\mathrm{CH}$, Willemsen $\mathrm{R}$, van Elzakker $\mathrm{P}$, van Steenbergen-Langeveld $\mathrm{S}$, Broertjes M, Oosterwijk-Wakka J, et al. Immune responses to transgene and retroviral vector in patients treated with ex vivo-engineered T cells. Blood. 2011;117(1):72-82.

14. Cao J, Wang G, Cheng H, Wei C, Qi K, Sang W, et al. Potent anti-leukemia activities of humanized CD19-targeted Chimeric antigen receptor $T$ (CAR-T) cells in patients with relapsed/refractory acute lymphoblastic leukemia. Am J Hematol. 2018;93(7):851-8.

15. Heng G, Jia JK, Li SQ, Fu G, Wang ML, Qin DB, et al. Sustained therapeutic efficacy of humanized anti-CD19 chimeric antigen receptor Tcells in relapsed/refractory acute lymphoblastic leukemia. Clin Cancer Res. 2020;26(7):1606-15

16. Long $\mathrm{AH}$, Haso WM, Shern JF, Wanhainen KM, Murgai M, Ingaramo $M$, et al. 4-1BB costimulation ameliorates $T$ cell exhaustion induced by tonic signaling of chimeric antigen receptors. Nat Med. 2015;21(6):581-90.

17. Calderon H, Mamonkin M, Guedan S. Analysis of CAR-mediated tonic signaling. Methods Mol Biol. 2020;2086:223-36.

18. Frigault MJ, Lee J, Basil MC, Carpenito C, Motohashi S, Scholler J, et al. Identification of chimeric antigen receptors that mediate constitutive or inducible proliferation of T cells. Cancer Immunol Res. 2015;3(4):356-67.
19. Ghorashian S, Kramer AM, Onuoha S, Wright G, Bartram J, Richardson $R$, et al. Enhanced CAR T cell expansion and prolonged persistence in pediatric patients with ALL treated with a low-affinity CD19 CAR. Nat Med. 2019;25(9):1408-14.

20. Hudecek M, Sommermeyer D, Kosasih PL, Silva-Benedict A, Liu LF, Rader $C$, et al. The nonsignaling extracellular spacer domain of chimeric antigen receptors is decisive for in vivo antitumor activity. Cancer Immunol Res. 2015;3(2):125-35.

21. Jonnalagadda M, Mardiros A, Urak R, Wang X, Hoffman $\sqcup$, Bernanke A et al. Chimeric antigen receptors with mutated lgG4 Fc spacer avoid fc receptor binding and improve $T$ cell persistence and antitumor efficacy. Mol Ther J Am Soc Gene Ther. 2015:23(4):757-68.

22. Alabanza L, Pegues M, Geldres C, Shi V, Wiltzius JJW, Sievers SA, et al. Function of novel anti-CD19 chimeric antigen receptors with human variable regions is affected by hinge and transmembrane domains. Mol Ther J Am Soc Gene Ther. 2017;25(11):2452-65.

23. Feucht J, Sun J, Eyquem J, Ho YJ, Zhao Z, Leibold J, et al. Calibration of CAR activation potential directs alternative $T$ cell fates and therapeutic potency. Nat Med. 2019;25(1):82-8.

24. Savoldo B, Ramos CA, Liu E, Mims MP, Keating MJ, Carrum G, et al. CD28 costimulation improves expansion and persistence of chimeric antigen receptor-modified T cells in lymphoma patients. J Clin Investig. 2011;121(5):1822-6.

25. Hombach A, Wieczarkowiecz A, Marquardt T, Heuser C, Usai L, Pohl C, et al. Tumor-specific T cell activation by recombinant immunoreceptors: CD3 zeta signaling and CD28 costimulation are simultaneously required for efficient $\mathrm{IL}-2$ secretion and can be integrated into one combined CD28/CD3 zeta signaling receptor molecule. J Immunol. 2001;167(11):6123-31.

26. Loskog A, Giandomenico V, Rossig C, Pule M, Dotti G, Brenner MK. Addition of the CD28 signaling domain to chimeric T-cell receptors enhances chimeric T-cell resistance to T regulatory cells. Leukemia. 2006;20(10):1819-28.

27. Kowolik CM, Topp MS, Gonzalez S, Pfeiffer T, Olivares S, Gonzalez N, et al. CD28 costimulation provided through a CD19-specific chimeric antigen receptor enhances in vivo persistence and antitumor efficacy of adoptively transferred T cells. Can Res. 2006;66(22):10995-1004.

28. Maher J, Brentjens RJ, Gunset G, Riviere I, Sadelain M. Human T-lymphocyte cytotoxicity and proliferation directed by a single chimeric TCRzeta/CD28 receptor. Nat Biotechnol. 2002;20(1):70-5.

29. Song DG, Ye Q, Poussin M, Harms GM, Figini M, Powell DJ Jr. CD27 costimulation augments the survival and antitumor activity of redirected human T cells in vivo. Blood. 2012;119(3):696-706.

30. Guedan S, Chen X, Madar A, Carpenito C, McGettigan SE, Frigault MJ, et al. ICOS-based chimeric antigen receptors program bipolar TH17/ TH1 cells. Blood. 2014;124(7):1070-80.

31. Hombach AA, Heiders J, Foppe M, Chmielewski M, Abken H. OX40 costimulation by a chimeric antigen receptor abrogates CD28 and IL-2 induced IL-10 secretion by redirected CD4(+) T cells. Oncoimmunology. 2012;1(4):458-66.

32. Zhong Q, Zhu YM, Zheng LL, Shen HJ, Ou RM, Liu Z, et al. Chimeric antigen receptor-T cells with 4-1BB co-stimulatory domain present a superior treatment outcome than those with CD28 domain based on bioinformatics. Acta Haematol. 2018;140(3):131-40.

33. Priceman SJ, Gerdts EA, Tilakawardane D, Kennewick KT, Murad JP, Park AK, et al. Co-stimulatory signaling determines tumor antigen sensitivity and persistence of CAR T cells targeting PSCA+ metastatic prostate cancer. Oncoimmunology. 2018;7(2):e1380764.

34. Li G, Boucher JC, Kotani H, Park K, Zhang Y, Shrestha B, et al. 4-1BB enhancement of CART function requires NF-kappaB and TRAFs. JCl Insight. 2018;3(18):e121322.

35. Guedan S, Madar A, Casado-Medrano V, Shaw C, Wing A, Liu F, et al. Single residue in CD28-costimulated CAR-T cells limits long-term persistence and antitumor durability. J Clin Investig. 2020;130(6):3087-97.

36. Gulati P, Ruhl J, Kannan A, Pircher M, Schuberth P, Nytko KJ, et al. Aberrant Lck signal via CD28 costimulation augments antigen-specific functionality and tumor control by redirected T cells with PD-1 blockade in humanized mice. Clin Cancer Res. 2018;24(16):3981-93.

37. Guedan S, Posey AD Jr, Shaw C, Wing A, Da T, Patel PR, et al. Enhancing CART cell persistence through ICOS and 4-1BB costimulation. JCI Insight. 2018;3(1):e96976. 
38. Guercio M, Orlando D, Di Cecca S, Sinibaldi M, Boffa I, Caruso S, et al. CD28.OX40 co-stimulatory combination is associated with long in vivo persistence and high activity of CAR.CD30 T-cells. Haematologica. 2020.

39. Lai Y, Weng J, Wei X, Qin L, Lai P, Zhao R, et al. Toll-like receptor 2 costimulation potentiates the antitumor efficacy of CART cells. Leukemia. 2018;32(3):801-8.

40. George P, Dasyam N, Giunti G, Mester B, Bauer E, Andrews B, et al. Thirdgeneration anti-CD19 chimeric antigen receptor T-cells incorporating a TLR2 domain for relapsed or refractory B-cell lymphoma: a phase I clinical trial protocol (ENABLE). BMJ Open. 2020;10(2):e034629.

41. Foster AE, Mahendravada A, Shinners NP, Chang WC, Crisostomo J, Lu A, et al. Regulated expansion and survival of chimeric antigen receptormodified T cells using small molecule-dependent inducible MyD88/ CD40. Mol Ther J Am Soc Gene Ther. 2017;25(9):2176-88.

42. Bourgeois C, Rocha B, Tanchot C. A role for CD40 expression on CD8 + T cells in the generation of CD8+ T cell memory. Science. 2002;297(5589):2060-3.

43. Bhadra R, Gigley JP, Khan IA. Cutting edge: CD40-CD40 ligand pathway plays a critical CD8-intrinsic and-extrinsic role during rescue of exhausted CD8 T cells. J Immunol. 2011;187(9):4421-5.

44. Collinson-Pautz MR, Chang WC, Lu A, Khalil M, Crisostomo JW, Lin PY, et al. Constitutively active MyD88/CD40 costimulation enhances expansion and efficacy of chimeric antigen receptor $T$ cells targeting hematological malignancies. Leukemia. 2019;33(9):2195-207.

45. Mata M, Gerken C, Nguyen P, Krenciute G, Spencer DM, Gottschalk S. Inducible activation of MyD88 and CD40 in CART cells results in controllable and potent antitumor activity in preclinical solid tumor models. Cancer Discov. 2017;7(11):1306-19.

46. He C, Zhou Y, Li Z, Faroog MA, Ajmal I, Zhang H, et al. Co-Expression of IL-7 improves NKG2D-based CART cell therapy on prostate cancer by enhancing the expansion and inhibiting the apoptosis and exhaustion. Cancers. 2020;12(7):1969.

47. Shum T, Omer B, Tashiro H, Kruse RL, Wagner DL, Parikh K, et al. Constitutive signaling from an engineered IL7 receptor promotes durable tumor elimination by tumor-redirected T cells. Cancer Discov. 2017;7(11):1238-47.

48. Luo H, Su J, Sun R, Sun Y, Wang Y, Dong Y, et al. Coexpression of IL7 and CCL21 increases efficacy of CAR-T cells in solid tumors without requiring preconditioned lymphodepletion. Clin Cancer Res. 2020;26:5494-505.

49. Adachi K, Kano Y, Nagai T, Okuyama N, Sakoda Y, Tamada K. IL-7 and CCL19 expression in CAR-T cells improves immune cell infiltration and CAR-T cell survival in the tumor. Nat Biotechnol. 2018;36(4):346-51.

50. Batra SA, Rathi P, Guo L, Courtney AN, Fleurence J, Balzeau J, et al. Glypican-3-specific CART cells coexpressing IL15 and IL21 have superior expansion and antitumor activity against hepatocellular carcinoma. Cancer Immunol Res. 2020;8(3):309-20.

51. Kagoya Y, Tanaka S, Guo T, Anczurowski M, Wang CH, Saso K, et al. A novel chimeric antigen receptor containing a JAK-STAT signaling domain mediates superior antitumor effects. Nat Med. 2018;24(3):352-9.

52. Pegram HJ, Lee JC, Hayman EG, Imperato GH, Tedder TF, Sadelain $M$, et al. Tumor-targeted T cells modified to secrete IL-12 eradicate systemic tumors without need for prior conditioning. Blood. 2012;119(18):4133-41.

53. Koneru M, Purdon TJ, Spriggs D, Koneru S, Brentjens RJ. IL-12 secreting tumor-targeted chimeric antigen receptor $T$ cells eradicate ovarian tumors in vivo. Oncoimmunology. 2015;4(3):e994446.

54. Ma X, Shou P, Smith C, Chen Y, Du H, Sun C, et al. Interleukin-23 engineering improves CART cell function in solid tumors. Nat Biotechnol. 2020;38(4):448-59.

55. Grewal IS, Xu J, Flavell RA. Impairment of antigen-specific T-cell priming in mice lacking CD40 ligand. Nature. 1995;378(6557):617-20.

56. Curran KJ, Seinstra BA, Nikhamin Y, Yeh R, Usachenko $Y$, van Leeuwen $D G$, et al. Enhancing antitumor efficacy of chimeric antigen receptor $T$ cells through constitutive CD40L expression. Mol Ther J Am Soc Gene Ther. 2015;23(4):769-78.

57. Zhao Z, Condomines M, van der Stegen SJC, Perna F, Kloss CC, Gunset $G$, et al. Structural design of engineered costimulation determines tumor rejection kinetics and persistence of CART cells. Cancer Cell. 2015:28(4):415-28.
58. Hu W, Huang X, Huang X, Chen W, Hao L, Chen Z. Chimeric antigen receptor modified T cell (CAR-T) co-expressed with ICOSL-41BB promote CAR-T proliferation and tumor rejection. Biomed Pharmacother. 2019;118:109333.

59. Stroncek DF, Ren J, Lee DW, Tran M, Frodigh SE, Sabatino M, et al. Myeloid cells in peripheral blood mononuclear cell concentrates inhibit the expansion of chimeric antigen receptor T cells. Cytotherapy. 2016;18(7):893-901.

60. Lynn RC, Weber EW, Sotillo E, Gennert D, Xu P, Good Z, et al. c-Jun overexpression in CART cells induces exhaustion resistance. Nature. 2019;576(7786):293-300.

61. Ruella M, Xu J, Barrett DM, Fraietta JA, Reich TJ, Ambrose DE, et al. Induction of resistance to chimeric antigen receptor $T$ cell therapy by transduction of a single leukemic B cell. Nat Med. 2018;24(10):1499-503.

62. Levine BL, Humeau LM, Boyer J, MacGregor RR, Rebello T, Lu X, et al. Gene transfer in humans using a conditionally replicating lentiviral vector. Proc Natl Acad Sci USA. 2006;103(46):17372-7.

63. Li Y, Kurlander RJ. Comparison of anti-CD3 and anti-CD28-coated beads with soluble anti-CD3 for expanding human T cells: differing impact on CD8 T cell phenotype and responsiveness to restimulation. J Transl Med. 2010;8:104.

64. Teschner D, Wenzel G, Distler E, Schnurer E, Theobald M, Neurauter AA, et al. In vitro stimulation and expansion of human tumour-reactive CD8+ cytotoxic T lymphocytes by anti-CD3/CD28/CD137 magnetic beads. Scand J Immunol. 2011;74(2):155-64.

65. Yang S, Dudley ME, Rosenberg SA, Morgan RA. A simplified method for the clinical-scale generation of central memory-like CD8+ T cells after transduction with lentiviral vectors encoding antitumor antigen T-cell receptors. J Immunother. 2010;33(6):648-58.

66. Eyquem J, Mansilla-Soto J, Giavridis T, van der Stegen SJ, Hamieh M, Cunanan KM, et al. Targeting a CAR to the TRAC locus with CRISPR/Cas9 enhances tumour rejection. Nature. 2017;543(7643):113-7.

67. Ghassemi S, Nunez-Cruz S, O'Connor RS, Fraietta JA, Patel PR, Scholler $J$, et al. Reducing Ex vivo culture improves the antileukemic activity of chimeric antigen receptor (CAR) T cells. Cancer Immunol Res. 2018:6(9):1100-9.

68. Kaartinen T, Luostarinen A, Maliniemi P, Keto J, Arvas M, Belt H, et al. Low interleukin-2 concentration favors generation of early memory $T$ cells over effector phenotypes during chimeric antigen receptor T-cell expansion. Cytotherapy. 2017;19(9):1130.

69. Zhang X, Lv X, Song Y. Short-term culture with IL-2 is beneficial for potent memory chimeric antigen receptor $T$ cell production. Biochem Biophys Res Commun. 2018;495(2):1833-8.

70. Hurton LV, Singh H, Najjar AM, Switzer KC, Mi T, Maiti S, et al. Tethered IL-15 augments antitumor activity and promotes a stem-cell memory subset in tumor-specific T cells. Proc Natl Acad Sci USA. 2016:113(48):E7788-97.

71. Alvarez-Fernandez C, Escriba-Garcia L, Vidal S, Sierra J, Briones J. A short CD3/CD28 costimulation combined with IL-21 enhance the generation of human memory stem $T$ cells for adoptive immunotherapy. J Transl Med. 2016;14(1):214.

72. Alizadeh D, Wong RA, Yang X, Wang D, Pecoraro JR, Kuo CF, et al. IL 15 enhances CAR-T cell antitumor activity by reducing mTORC1 activity and preserving their stem cell memory phenotype. Cancer Immunol Res. 2019;7(5):759-72.

73. Wherry EJ. T cell exhaustion. Nat Immunol. 2011;12(6):492-9.

74. Zheng W, O'Hear CE, Alli R, Basham JH, Abdelsamed HA, Palmer LE, et al. PI3K orchestration of the in vivo persistence of chimeric antigen receptor-modified T cells. Leukemia. 2018;32(5):1157-67.

75. Petersen $C T$, Hassan M, Morris AB, Jeffery J, Lee $K$, Jagirdar N, et al. Improving T-cell expansion and function for adoptive T-cell therapy using ex vivo treatment with PI3Kdelta inhibitors and VIP antagonists. Blood Adv. 2018;2(3):210-23.

76. Ebert PJR, Cheung J, Yang Y, McNamara E, Hong R, Moskalenko M, et al. MAP kinase inhibition promotes T cell and anti-tumor activity in combination with PD-L1 checkpoint blockade. Immunity. 2016;44(3):609-21.

77. Klebanoff CA, Crompton JG, Leonardi AJ, Yamamoto TN, Chandran SS, Eil RL, et al. Inhibition of AKT signaling uncouples T cell differentiation from expansion for receptor-engineered adoptive immunotherapy. JCI Insight. 2017;2(23):e95103. 
78. Urak R, Walter M, Lim L, Wong CW, Budde LE, Thomas S, et al. Ex vivo Akt inhibition promotes the generation of potent CD19CART cells for adoptive immunotherapy. J Immunother Cancer. 2017;5:26.

79. Yang Y, Kohler ME, Chien CD, Sauter CT, Jacoby E, Yan C, et al. TCR engagement negatively affects CD8 but not CD4 CART cell expansion and leukemic clearance. Sci Transl Med. 2017;9(417):eaag1209.

80. Ghosh A, Smith M, James SE, Davila ML, Velardi E, Argyropoulos KV, et al. Donor CD19 CAR T cells exert potent graft-versus-lymphoma activity with diminished graft-versus-host activity. Nat Med. 2017;23(2):242-9.

81. Stenger D, Stief TA, Kaeuferle T, Willier S, Rataj F, Schober K, et al. Endogenous TCR promotes in vivo persistence of CD19-CAR-T cells compared to a CRISPR/Cas9-mediated TCR knockout CAR. Blood. 2020;136(12):1407-18.

82. Henning AN, Roychoudhuri R, Restifo NP. Epigenetic control of CD8(+) T cell differentiation. Nat Rev Immunol. 2018;18(5):340-56.

83. Carty SA, Gohil M, Banks LB, Cotton RM, Johnson ME, Stelekati E, et al. The loss of TET2 promotes CD8(+) T cell memory differentiation. J Immunol. 2018;200(1):82-91.

84. Fraietta JA, Nobles CL, Sammons MA, Lundh S, Carty SA, Reich TJ, et al. Disruption of TET2 promotes the therapeutic efficacy of CD19-targeted T cells. Nature. 2018;558(7709):307-12.

85. Ladle BH, Li KP, Phillips MJ, Pucsek AB, Haile A, Powell JD, et al. De novo DNA methylation by DNA methyltransferase 3a controls early effector CD8+ T-cell fate decisions following activation. Proc Natl Acad Sci USA. 2016;113(38):10631-6.

86. You L, Han Q, Zhu L, Zhu Y, Bao C, Yang C, et al. Decitabine-mediated epigenetic reprograming enhances anti-leukemia efficacy of CD123-targeted chimeric antigen receptor T-cells. Front Immunol. 2020;11:1787.

87. Ghoneim HE, Fan Y, Moustaki A, Abdelsamed HA, Dash P, Dogra P, et al. De Novo epigenetic programs inhibit PD-1 blockade-mediated T cell rejuvenation. Cell. 2017;170(1):142-5719.

88. Maus MV, Fraietta JA, Levine BL, Kalos M, Zhao Y, June CH. Adoptive immunotherapy for cancer or viruses. Annu Rev Immunol. 2014:32:189-225.

89. Wang X, Naranjo A, Brown CE, Bautista C, Wong CW, Chang WC, et al. Phenotypic and functional attributes of lentivirus-modified CD19specific human $\mathrm{CD} 8+$ central memory $T$ cells manufactured at clinical scale. J Immunother. 2012;35(9):689-701.

90. Terakura S, Yamamoto TN, Gardner RA, Turtle CJ, Jensen MC, Riddell SR. Generation of CD19-chimeric antigen receptor modified CD8+ $T$ cells derived from virus-specific central memory $T$ cells. Blood. 2012;119(1):72-82.

91. Taniuchi I. CD4 helper and CD8 cytotoxic T cell differentiation. Annu Rev Immunol. 2018;36:579-601.

92. Xhangolli I, Dura B, Lee G, Kim D, Xiao Y, Fan R. Single-cell analysis of CAR-T cell activation reveals a mixed $\mathrm{TH} 1 / \mathrm{TH} 2$ response independent of differentiation. Genomics Proteomics Bioinform. 2019;17(2):129-39.

93. Agarwal S, Hanauer JDS, Frank AM, Riechert V, Thalheimer FB, Buchholz CJ. In vivo generation of CAR T cells selectively in human CD4(+) lymphocytes. Mol Ther J Am Soc Gene Ther. 2020;28(8):1783-94.

94. Liadi I, Singh H, Romain G, Rey-Villamizar N, Merouane A, Adolacion JR, et al. Individual motile CD4(+) T cells can participate in efficient multikilling through conjugation to multiple tumor cells. Cancer Immunol Res. 2015;3(5):473-82.

95. Wang D, Aguilar B, Starr R, Alizadeh D, Brito A, Sarkissian A, et al. Glioblastoma-targeted CD4+ CAR T cells mediate superior antitumor activity. JCl Insight. 2018;3(10):e99048.

96. Liadi I, Singh H, Romain G, Roysam B, Cooper LJ, Varadarajan N. Defining potency of CAR(+)T cells: fast and furious or slow and steady. Oncoimmunology. 2019;8(10):e1051298

97. Sommermeyer D, Hudecek M, Kosasih PL, Gogishvili T, Maloney DG, Turtle CJ, et al. Chimeric antigen receptor-modified T cells derived from defined CD8+ and CD4+ subsets confer superior antitumor reactivity in vivo. Leukemia. 2016;30(2):492-500.

98. Turtle CJ, Hanafi LA, Berger C, Gooley TA, Cherian S, Hudecek M, et al. CD19 CAR-T cells of defined CD4+:CD8+ composition in adult B cell ALL patients. J Clin Investig. 2016;126(6):2123-38.

99. Bryan LJ, Gordon LI. Releasing the brake on the immune system: the PD-1 strategy for hematologic malignancies. Oncology. 2015;29(6):431-9.
100. Rosenberg SA, Restifo NP. Adoptive cell transfer as personalized immunotherapy for human cancer. Science. 2015;348(6230):62-8.

101. Ninomiya S, Narala N, Huye L, Yagyu S, Savoldo B, Dotti G, et al. Tumor indoleamine 2,3-dioxygenase (IDO) inhibits CD19-CAR T cells and is downregulated by lymphodepleting drugs. Blood. 2015;125(25):3905-16.

102. Mussai F, De Santo C, Abu-Dayyeh I, Booth S, Quek L, McEwen-Smith $\mathrm{RM}$, et al. Acute myeloid leukemia creates an arginase-dependent immunosuppressive microenvironment. Blood. 2013;122(5):749-58.

103. Kloss CC, Lee J, Zhang A, Chen F, Melenhorst JJ, Lacey SF, et al. Dominant-negative TGF-beta receptor enhances PSMA-targeted human CAR T cell proliferation and augments prostate cancer eradication. Mol Ther J Am Soc Gene Ther. 2018;26(7):1855-66.

104. Mohammed S, Sukumaran S, Bajgain P, Watanabe N, Heslop HE, Rooney $\mathrm{CM}$, et al. Improving chimeric antigen receptor-modified T cell function by reversing the immunosuppressive tumor microenvironment of pancreatic cancer. Mol Ther J Am Soc Gene Ther. 2017;25(1):249-58.

105. Gajewski TF, Meng Y, Blank C, Brown I, Kacha A, Kline J, et al. Immune resistance orchestrated by the tumor microenvironment. Immunol Rev. 2006;213:131-45.

106. Lee JC, Hayman E, Pegram HJ, Santos E, Heller G, Sadelain M, et al. In vivo inhibition of human CD19-targeted effector T cells by natural T regulatory cells in a xenotransplant murine model of B cell malignancy. Can Res. 2011;71(8):2871-81.

107. Beatty GL, Moon EK. Chimeric antigen receptor T cells are vulnerable to immunosuppressive mechanisms present within the tumor microenvironment. Oncoimmunology. 2014;3(11):e970027.

108. Moon EK, Wang LC, Dolfi DV, Wilson CB, Ranganathan R, Sun J, et al. Multifactorial T-cell hypofunction that is reversible can limit the efficacy of chimeric antigen receptor-transduced human T cells in solid tumors. Clin Cancer Res. 2014;20(16):4262-73.

109. Chong EA, Melenhorst JJ, Lacey SF, Ambrose DE, Gonzalez V, Levine BL, et al. PD-1 blockade modulates chimeric antigen receptor (CAR)-modified T cells: refueling the CAR. Blood. 2017;129(8):1039-41.

110. Lutsiak ME, Semnani RT, De Pascalis R, Kashmiri SV, Schlom J, Sabzevari $\mathrm{H}$. Inhibition of CD4(+)25+ T regulatory cell function implicated in enhanced immune response by low-dose cyclophosphamide. Blood. 2005;105(7):2862-8.

111. Long AH, Highfill SL, Cui YZ, Smith JP, Walker AJ, Ramakrishna S, et al. Reduction of MDSCs with all-trans retinoic acid improves CAR therapy efficacy for sarcomas. Cancer Immunol Res. 2016;4(10):869-80.

112. Alizadeh D, Trad M, Hanke NT, Larmonier CB, Janikashvili N, Bonnotte $B$, et al. Doxorubicin eliminates myeloid-derived suppressor cells and enhances the efficacy of adoptive T-cell transfer in breast cancer. Can Res. 2014;74(1):104-18.

113. Kakarla S, Chow KK, Mata M, Shaffer DR, Song XT, Wu MF, et al. Antitumor effects of chimeric receptor engineered human T cells directed to tumor stroma. Mol Ther J Am Soc Gene Ther. 2013;21(8):1611-20.

114. Sabatino M, Hu J, Sommariva M, Gautam S, Fellowes V, Hocker JD, et al. Generation of clinical-grade CD19-specific CAR-modified CD8+ memory stem cells for the treatment of human B-cell malignancies. Blood. 2016;128(4):519-28.

115. Xu Y, Zhang M, Ramos CA, Durett A, Liu E, Dakhova O, et al. Closely related T-memory stem cells correlate with in vivo expansion of CAR.CD19-T cells and are preserved by IL-7 and IL-15. Blood. 2014;123(24):3750-9.

116. Fraietta JA, Lacey SF, Orlando EJ, Pruteanu-Malinici I, Gohil M, Lundh $S$, et al. Determinants of response and resistance to CD19 chimeric antigen receptor (CAR) T cell therapy of chronic lymphocytic leukemia. Nat Med. 2018;24(5):563-71.

117. Kaech SM, Cui W. Transcriptional control of effector and memory CD8+ T cell differentiation. Nat Rev Immunol. 2012;12(11):749-61.

118. Yu B, Zhang K, Milner JJ, Toma C, Chen R, Scott-Browne JP, et al. Epigenetic landscapes reveal transcription factors that regulate CD8(+) T cell differentiation. Nat Immunol. 2017;18(5):573-82.

119. Masopust D, Schenkel JM. The integration of T cell migration, differentiation and function. Nat Rev Immunol. 2013;13(5):309-20.

120. Wherry EJ, Kurachi M. Molecular and cellular insights into T cell exhaustion. Nat Rev Immunol. 2015;15(8):486-99.

121. Pauken KE, Wherry EJ. Overcoming T cell exhaustion in infection and cancer. Trends Immunol. 2015;36(4):265-76. 
122. Chen J, Lopez-Moyado IF, Seo H, Lio CJ, Hempleman LJ, Sekiya T, et al. NR4A transcription factors limit CART cell function in solid tumours. Nature. 2019;567(7749):530-4.

123. Liu X, Wang Y, Lu H, Li J, Yan X, Xiao M, et al. Genome-wide analysis identifies NR4A1 as a key mediator of T cell dysfunction. Nature. 2019;567(7749):525-9.

124. Seo H, Chen J, Gonzalez-Avalos E, Samaniego-Castruita D, Das A, Wang $\mathrm{YH}$, et al. TOX and TOX2 transcription factors cooperate with NR4A transcription factors to impose CD8(+) T cell exhaustion. Proc Natl Acad Sci USA. 2019;116(25):12410-5.

125. Khan O, Giles JR, McDonald S, Manne S, Ngiow SF, Patel KP, et al. TOX transcriptionally and epigenetically programs $\mathrm{CD} 8(+) \mathrm{T}$ cell exhaustion. Nature. 2019;571(7764):211-8.

126. Hokey DA, Johnson FB, Smith J, Weber JL, Yan J, Hirao L, et al. Activation drives PD-1 expression during vaccine-specific proliferation and following lentiviral infection in macaques. Eur J Immunol. 2008;38(5):1435-45.

127. Rafiq S, Yeku OO, Jackson HJ, Purdon TJ, van Leeuwen DG, Drakes DJ, et al. Targeted delivery of a PD-1-blocking scFv by CAR-T cells enhances anti-tumor efficacy in vivo. Nat Biotechnol. 2018;36(9):847-56.

128. Rupp LJ, Schumann K, Roybal KT, Gate RE, Ye CJ, Lim WA, et al. CRISPR/ Cas9-mediated PD-1 disruption enhances anti-tumor efficacy of human chimeric antigen receptor T cells. Sci Rep. 2017;7(1):737.
129. Marotte L, Simon S, Vignard V, Dupre E, Gantier M, Cruard J, et al. Increased antitumor efficacy of PD-1-deficient melanoma-specific human lymphocytes. J Immunother Cancer. 2020;8(1):e000311.

130. Cherkassky L, Morello A, Villena-Vargas J, Feng Y, Dimitrov DS, Jones DR, et al. Human CART cells with cell-intrinsic PD-1 checkpoint blockade resist tumor-mediated inhibition. J Clin Investig. 2016;126(8):3130-44.

131. Zolov SN, Rietberg SP, Bonifant CL. Programmed cell death protein 1 activation preferentially inhibits CD28.CAR-T cells. Cytotherapy. 2018;20(10):1259-66

132. Zou F, Lu L, Liu J, Xia B, Zhang W, Hu Q, et al. Engineered triple inhibitory receptor resistance improves anti-tumor CAR-T cell performance via CD56. Nat Commun. 2019;10(1):4109.

133. Mamonkin M, Heslop HE. Exhausting alloreactivity of donor-derived CART cells. Nat Med. 2017;23(2):147-8.

134. Yu S, Yi M, Qin $S$, Wu K. Next generation chimeric antigen receptor T cells: safety strategies to overcome toxicity. Mol Cancer. 2019;18(1):125.

\section{Publisher's Note}

Springer Nature remains neutral with regard to jurisdictional claims in published maps and institutional affiliations.
Ready to submit your research? Choose BMC and benefit from:

- fast, convenient online submission

- thorough peer review by experienced researchers in your field

- rapid publication on acceptance

- support for research data, including large and complex data types

- gold Open Access which fosters wider collaboration and increased citations

- maximum visibility for your research: over $100 \mathrm{M}$ website views per year

At BMC, research is always in progress.

Learn more biomedcentral.com/submissions 